УДК $355.586+004.89$

Євсюков Олександр,

д-р держ. упр., доц.

ORCID iD 0000-0001-8586-9896,

E-mail: kafedra_dsunmp@ukr.net

Гаваза Андрій,

ORCID iD $\underline{\text { 0000-0002-7205-410X }}$

\title{
ОРГАНІЗАЦІЙНО-МЕТОДИЧНІ ЗАСАДИ ВІДБОРУ ЗМІСТУ НОВІТНІХ ТЕХНОЛОГІЙ ПІДВИЩЕННЯ КВАЛІФІКАЦІЇ УПРАВЛІНСЬКИХ КАДРІВ СФЕРИ ЦИВІЛЬНОГО ЗАХИСТУ
}

https://doi.org/10.32689/2618-0065-2020-4(6)-93-121

\begin{abstract}
Анотація. Реформування системи цивільного захисту держави, яке було проведене останніми роками, життя в умовах ринкових відносин, новітніх інформаційних технологій, закордонний досвід розвинутих держав потребує переосмислення існуючої практики підготовки кадрів для реалізації заходів безпеки населення і територій України 3 урахуванням європейських стандартів управління ризиками. До основних складових змісту підвищення кваліфікації управлінських кадрів в інститутах підвищення кваліфікації та ЗВО мають відносити змістові модулі: законодавчої, культуротворчої та українознавчої спрямованості; світоглядної (сучасної методологічної), психологічної й фасилітативної підготовки; з філософії, політики, парламентаризму, державного управління, права, інноватики, інформатики тощо. Визначення змісту підвищення кваліфікації керівних кадрів відбувається під впливом політичних і соціально-економічних змін, які відбуваються в суспільстві; виявляє тенденцію орієнтації не лише на вимоги держави, а й на особистісні і професійні запити слухачів; спрямовується на оновлення всієї системи безперервного професійного розвитку управлінських кадрів, а саме: на врахування тенденцій розвитку суспільства, на опанування нового змісту та освітніх технологій, на впровадження інновацій, на розвиток уміння зіставляти локальні проблеми своєї професійної діяльності із загальнодержавними
\end{abstract}




\section{Науковий вісник: Державне управління № 4(6)2020}

пріоритетами, на вмотивованість власного професійного зростання. Механізмом реалізації безпекової теорії $є$ публічне управління у сфері цивільного захисту, що має мультидисциплінарний характер, поєднуючи методологію та інструментарій супільно-гуманітарних, природничих i технічних наук, опрацьовуючи новий безпековий світогляд, культуру сталого розвитку. Ефективність професійної діяльності фахівців у сфері цивільного захисту, пов'язана 3 понаднормованими психоемоційними і фізичними навантаженнями, має бути забезпечена застосуванням високотехнологічних та інноваційних методів навчання 3 урахуванням специфіки діяльності органів управління і підрозділів служби цивільного захисту. Зважаючи на це, функціональна компетенція, тобто знання і вміння виконувати певні типи діяльності та типові для даної функцї завдання діяльності, для публічних управлінців у сфері цивільного захисту стає головним видом компетенцї.

Ключові слова: управлінські кадри, цивільний захист, кваліфікація, компетенція, підготовка.

Постановка проблеми. Процеси оновлення системи державного управління, зокрема, модернізації державної служби України, що відбуваються на сучасному етапі державотворення, ставлять нові вимоги до професійних i особистісних якостей державних службовців, рівня їх професіоналізму та компетентності. Тому питання удосконалення діючої нині системи підготовки, перепідготовки та підвищення кваліфікації державних службовців в Україні, перетворення іiі на випереджуючу безперервну професійну освіту фахівців даної галузі набуває особливого значення. На цей час персонал державної служби недостатньо підготовлений до інноваційної діяльності, здійснення суспільних реформ. Існуючі підходи до професійного навчання державних службовців не повною мірою відповідають сучасним вимогам, європейським стандартам і пріоритетам нової державної кадрової політики.

Реформування системи цивільного захисту держави, яке було проведене останніми роками, життя в умовах ринкових відносин, новітніх інформаційних технологій, закордонний 
досвід розвинутих держав потребує переосмислення існуючої практики підготовки кадрів для реалізації заходів безпеки населення і територій України з урахуванням європейських стандартів управління ризиками.

У сфері цивільного захисту організація навчання здійснюється 3 метою забезпечення потреб центральних i місцевих органів виконавчої влади, органів місцевого самоврядування, державних підприємств, установ та організацій, на яких поширюється дія законів у сфері захисту населення i територій від $\mathrm{HC}$ (надзвичайних ситуацій) техногенного та природного характеру (далі - у сфері цивільного захисту), у працівниках, здатних компетентно i відповідально виконувати функції управління техногенною i природною безпекою населення, територій та об'єктів господарської діяльності, впроваджувати технології, спрямовані на зменшення ризиків виникнення і мінімізацію наслідків НС та їх ліквідацію.

Життя в умовах ринкових відносин, новітніх інформаційних технологій потребує переосмислення існуючої практики підготовки кадрів для реалізації заходів безпеки населення і територій України.

Аналіз змісту роботи державних службовців показав, що надзвичайно широке коло різнопланових повноважень i практичних завдань вирішується за допомогою технологічних функцій. Головні серед них - контрольно-аналітичні, організаційно-управлінські та інформаційно-комунікаційні. Кожен 3 них має свої цільові орієнтири, принципи і певні набори соціальних технологій, накопичених практичним досвідом, які забезпечують успішну реалізацію завдань у різних типових соціальних ситуаціях.

Професіоналізація $\epsilon$ важливою умовою розвитку державної служби в Україні, про що свідчать такі суттєві ознаки, як: наявність стійкої суспільної потреби в державному управлінні, формування специфічного комплексу трудових функцій i професійних стандартів; інституціоналізація 
Науковий вісник: Державне управління № 4(6)2020

трудових відносин, розвиток інститутів індивідуальної професіоналізації, передусім професійного навчання тощо.

Формування професіоналізму виступає як процес проходження психофізіологічних особистісних змін, які відбуваються під час тривалого виконання людиною службових обов'язків, що забезпечують якісно новий, більш ефективний рівень вирішення складних професійних завдань в особливих умовах.

Аналіз останніх досліджень і публікацій. У науці і практичній діяльності закріпилася особистісно-діяльнісна парадигма професіоналізму, яка базується на системних уявленнях про становлення особистості в професійній діяльності.

Однією 3 надважливих особливостей професійної діяльності державних службовців $є$ іï спрямованість на підготовку, прийняття та реалізацію управлінських рішень [1], що є особливо актуальним в умовах виникнення НС.

Вивчаючи світовий досвід підготовки та перепідготовки державних службовців [2-6] є можливим виокремити наступні параметри: статус державного службовця унормований законодавством; обов'язковою умовою для вступу на державну службу $є$ наявність базової освіти та профільної підготовки; регулярне проходження різних програм підвищення кваліфікації та періодичне проходження стажування. Грунтуючись на власному досвіді [7, 8] та джерелах наукової інформації [9-11] можна стверджувати, що підвищення ефективності праці державних службовців нерозривно пов'язано 3 розвитком міждисциплінарного підходу до формування програм навчання, орієнтованого на розвиток у майбутніх державних службовців системного мислення, комунікабельності, вміння працювати в команді, самостійності та ініціативності.

Новели Положення про систему професійного навчання державних службовців, голів місцевих державних адміністрацій, їх перших заступників та заступників, 


\section{Науковий вісник: Державне управління № 4(6)2020}

посадових осіб місцевого самоврядування та депутатів місцевих рад, затвердженого постановою Кабінету Міністрів України від 06.02.2019 № 106, визначають організаційні засади функціонування системи професійного навчання державних службовців, голів місцевих державних адміністрацій, їх перших заступників та заступників, посадових осіб місцевого самоврядування та депутатів місцевих рад 3 урахуванням вимог академічної доброчесності. Тобто, наразі започатковано створення сучасної системи професійного навчання 3 урахуванням принципів навчання протягом життя.

Акцентується увага на тому, що система професійного навчання створюється для задоволення потреб державних органів та органів місцевого самоврядування, на які поширюється дія Законів України «Про державну службу», «Про службу в органах місцевого самоврядування», «Про місцеві державні адміністрації», «Про місцеве самоврядування в Україні», у високопрофесійних фахівцях і забезпечення умов для підвищення рівня професійної компетентності учасників професійного навчання.

Підвищення кваліфікації здійснюється за програмами, які за змістом навчання поділяються на загальні і спеціальні.

Загальні програми підвищення кваліфікації - програми підвищення кваліфікації, метою яких $є$ підвищення рівня професійної компетентності учасників професійного навчання на основі раніше набутого професійного та життєвого досвіду та відповідно до загальних потреб державних органів, органів місцевого самоврядування.

Зміст загальних програм підвищення кваліфікації охоплює загальні питання державного управління та місцевого самоврядування, питання запобігання корупції, зміни у законодавстві з питань державної служби, служби в органах місцевого самоврядування, європейської та євроатлантичної інтеграції, питання забезпечення рівних прав та можливостей жінок та чоловіків, підвищення рівня володіння іноземною мовою, яка $є$ офіційною мовою Ради Європи, державною 
Науковий вісник: Державне управління № 4(6)2020

мовою, а також інші питання, визначені відповідними державними, регіональними, місцевими програмами, стратегіями.

Спеціальні програми підвищення кваліфікації - програми підвищення кваліфікації, метою яких $є$ підвищення рівня професійної компетентності учасників професійного навчання на основі раніше набутого професійного та життєвого досвіду та відповідно до їх індивідуальних потреб і спеціальних потреб державних органів, органів місцевого самоврядування.

Зміст спеціальних програм підвищення кваліфікації охоплює питання функціонування та основних напрямів діяльності окремого державного органу, органу місцевого самоврядування.

Очікувані результати навчання за загальними та спеціальними програмами підвищення кваліфікації мають охоплювати професійні знання та професійні компетентності, необхідні учасникам професійного навчання для належного виконання ними встановлених завдань і обов'язків.

Програми підвищення кваліфікації можуть передбачати очну (денну, вечірню), дистанційну та змішану (очну та дистанційну з використанням спеціальних інтернет-платформ, веб-сайтів тощо) форми навчання.

Мета статті - визначити організаційно-методичні засади відбору змісту та організації сучасної системи підвищення кваліфікації управлінських кадрів сфери цивільного захисту.

Виклад основного матеріалу. Основою відбору змісту підвищення кваліфікації є професіографічний аналіз посадових обов'язків державних службовців. Компетентність, професіоналізм державних службовців на всіх етапах розвитку державної служби зумовлює успішність реалізації ії цілей та завдань.

Поглиблення політичних, економічних, соціальних взаємозв'язків на тлі широкого інформаційного поля формує суспільний запит на управлінців нової генерації. Сучасний державний службовець для громадян - не безособова штатна 


\section{Науковий вісник: Державне управління № 4(6)2020}

одиниця певної установи, не чиновник: споживачі послуг чекають від нього компетентного рішення своїх проблем та запитів.

Відгукуючись на суспільну потребу триває формування безпекової теорії світового співтовариства, що спирається на еколого-природозахисні, економіко-технологічні, соціальнополітичні та воєнні аспекти. Механізмом реалізації безпекової теорії $є$ публічне управління у сфері цивільного захисту, що має мультидисциплінарний характер, поєднуючи методологію та інструментарій супільно-гуманітарних, природничих i технічних наук, опрацьовуючи новий безпековий світогляд, культуру сталого розвитку.

Ефективність професійної діяльності фахівців у сфері цивільного захисту, пов'язана 3 понаднормованими психоемоційними i фізичними навантаженнями, має бути забезпечена застосуванням високотехнологічних та інноваційних методів навчання 3 урахуванням специфіки діяльності органів управління і підрозділів служби цивільного захисту.

Зважаючи на це, функціональна компетентність, тобто знання і вміння виконувати певні типи діяльності та типові для даної функції завдання діяльності, для публічних управлінців у сфері цивільного захисту стає головним видом компетенції.

Чисельність моделей діяльності державних органів управління збільшується, урізноманітнюються способи досягнення мети, але кожний 3 них висуває вимогу персональної відповідальності державних службовців за результати прийнятих ними рішень.

Фактично їх обов'язком стає створення умов для формування соціально-економічного балансу між потребами економіки та соціальними потребами суспільства. Звідси постає потреба трансформації управлінської ролі суб'єктів державного управління, іншого змістового наповнення їх діяльності, нового погляду на професійність, яка 3 сукупності "загальнотеоретичних, спеціальних управлінських i 
психологічних знань, умінь і навичок" [17] перетворюється на систему професійних компетенцій у складі професійної компетентності працівника, здатного до ефективної діяльності в змінюваних умовах. Відтак набуває актуальності компетентнісний підхід до формування професійності державних службовців.

Компетентнісний підхід у світовому освітньому просторі XXI століття уособлює інноваційний процес в освіті, відповідає прийнятій у більшості розвинених країн єдиній (порівняльній) концепції освітнього стандарту i прямо пов'язаний $з$ переходом на систему компетенцій.

Компетентністний підхід - головний дескриптор прийнятої в 2006 р. «Свропейської кваліфікаційної рамки» («European qualifications framework lifelong learning») - в якості цільової підсистеми, поряд із знаннями та навичками, виділяє підсистему компетенцій (competence). Цільовою функцією реалізації даного підходу є формування потрібного профілю компетенцій учня [18].

Грунтуючись на власних дослідженнях [19] та наукових здобутках інших вчених [10] розроблено модель компетентностей керівника органу державної влади (табл. 1).

Всередині компетентнісного підходу виділяються два базових поняття: компетенція і компетентність, при цьому перший з них «включає сукупність взаємопов'язаних якостей особистості, що задаються по відношенню до певного кола предметів і процесів», а друге співвідноситься 3 «володінням, володінням людиною відповідною компетенцією, що включає його особистісне ставлення до неї і предмету діяльності».

Окрім знань, умінь і навичок додаються нові компоненти: особистісні, соціальні, комунікативні, інформаційні, освітні компетенції.

Список нових компонент в результаті розширюється, розмірність вектору стану освіченості слухача при цьому також збільшується. 
Науковий вісник: Державне управління № 4(6)2020

Таблиця 1 - Формалізована модель компетентності керівника органу державної служби

\begin{tabular}{|c|c|}
\hline $\begin{array}{l}\text { Найменування групи } \\
\text { компетенцій }\end{array}$ & Зміст компетенцій \\
\hline \multicolumn{2}{|c|}{ 1. Загальноуправлінські компетентності } \\
\hline \multicolumn{2}{|c|}{ БАЗОВІ УПРАВЛІНСЬКІ } \\
\hline когнітивні & $\begin{array}{l}\text { Знання організаційного } \\
\text { фуеханізму } \\
\text { влади, Конституції } \\
\text { законодавства України, } \\
\text { службу, пе } \\
\text { забезпечення дермативно-правового } \\
\text { відповідного органу дунціонування } \\
\text { влади. }\end{array}$ \\
\hline функціональні & $\begin{array}{l}\text { Вміння оцінювати переваги та } \\
\text { недоліки організаційно-правових } \\
\text { форм управління, здійснювати } \\
\text { управління організаційною } \\
\text { структурою. } \\
\text { Аналітичні вміння. }\end{array}$ \\
\hline \multicolumn{2}{|c|}{ КОМПЕТЕНТНОСТІ У СФЕРІ УПРАВЛІННЯ ПЕРСОНАЛОМ } \\
\hline когнітивні & $\begin{array}{l}\text { Знання методів у управління } \\
\text { людськими ресурсами } \\
\text { організаціях. } \\
\text { Знання організаційної структури і } \\
\text { організаційних змін. } \\
\text { Знання методів планування і } \\
\text { організації роботи з персоналом. }\end{array}$ \\
\hline функціональні & $\begin{array}{l}\text { Уміння здійснювати ефективні } \\
\text { комунікації, презентації, ділову } \\
\text { переписку. } \\
\text { Навички володіння різноманітними } \\
\text { методами управління конфліктами, } \\
\text { здійснення організаційних змін. } \\
\text { Вміння формувати команду та } \\
\text { ефективно працювати в ній. }\end{array}$ \\
\hline
\end{tabular}


Науковий вісник: Державне управління № 4(6)2020

\begin{tabular}{|c|c|}
\hline $\begin{array}{l}\text { Найменування групи } \\
\text { компетенцій } \\
\end{array}$ & Зміст компетенцій \\
\hline \multicolumn{2}{|c|}{ САМОМЕНЕДЖМЕНТ } \\
\hline когнітивні & $\begin{array}{l}\text { Знання методів управління часом, } \\
\text { самоаналізу та самоменеджменту. }\end{array}$ \\
\hline функціональні & $\begin{array}{l}\text { Навички веденні переговорів, } \\
\text { знання ділового етикету, вміння } \\
\text { проводити презентації. } \\
\text { Уміння організовувати власний час. } \\
\text { Уміння проводити самоаналіз. }\end{array}$ \\
\hline особистісні & $\begin{array}{l}\text { Уміння розпізнавати у собі } \\
\text { лідерські якості. } \\
\text { Знання загального рівня культури, } \\
\text { ерудиція. } \\
\text { Ініціативність. }\end{array}$ \\
\hline \multicolumn{2}{|c|}{$\begin{array}{l}\text { 2. Компетентності, пов'язані з розвитком і функціонуванням } \\
\text { організації }\end{array}$} \\
\hline функціональні & $\begin{array}{l}\text { Знання теорії державного } \\
\text { управління. } \\
\text { Знання методів управління у сфері } \\
\text { діяльності центрального органу } \\
\text { державної влади. } \\
\text { Уміння управляти ризиками. }\end{array}$ \\
\hline особистісні & $\begin{array}{l}\text { Забезпечує проведення державної } \\
\text { політики у відповідній сфері, } \\
\text { розробляє та впроваджує механізми } \\
\text { іiі реалізації. } \\
\text { Координує прогнозування розвитку } \\
\text { відповідної галузі національної } \\
\text { економіки та сфери діяльності. } \\
\text { Забезпечує здійснення заходів } \\
\text { координації державного управління } \\
\text { у відповідній сфері. }\end{array}$ \\
\hline
\end{tabular}

Завдання освітньої програми в такому випадку полягає не тільки в забезпеченні освоєння слухачем нових компетенцій, а й розширення області освіченості слухача при одночасному вирішенні можливих конфліктів навичок і знань.

Реалізація компетентнісного підходу у підвищенні кваліфікації державних службовців та посадових осіб 
Науковий вісник: Державне управління № 4(6)2020

місцевого самоврядування передбачає постійне вдосконалення освітніх технологій, розвиток активних форм і методів навчання, що включає аналіз конкретних ситуацій, комунікативні та управлінські тренінги, ділові ігри тощо.

3 цією метою необхідно передбачити проведення інтерактивних занять, що направлені на формування і розвиток навичок роботи в команді, проектних навичок, прийомів i методів мотиваційного впливу на інших людей, розвиток когнітивних, функціональних, особистісних i етичних компетенцій, розвиток яких забезпечуватиметься:

a) при аналізі конкретних ситуацій і в ході пошуку рішень поставлених завдань;

б) проведенні ділових і рольових ігор;

в) комунікативних і управлінських тренінгах;

г) проведенні практикумів;

д) презентаціях розроблених слухачами проектів.

Застосування компетентністного підходу сприятиме досягненню однієї з ключових цілей управління людськими ресурсами - узгодження інтересів організації та індивіда шляхом фокусування уваги на аспектах розвитку та «винагороди за знання». Система винагороди за компетенції орієнтує співробітників на набуття нових навичок, професій, знань, що забезпечує постійне підвищення якості людських ресурсів організації.

Методологічним підгрунтям відбору змісту та технології підвищення кваліфікації управлінських кадрів $є$ принципи їх відбору, до яких в теорії віднесені - актуальність, стандартизація, структурованість, варіативність, диференціація.

Крім того, важливими принципами відбору змісту підвищення кваліфікації управлінських кадрів віднесено такі:

пріоритет самостійного навчання (в сенсі самостійної організації слухачами процесу свого навчання; 
пріоритет спільної діяльності (спільна діяльність слухача 3 викладачем, а також іншими слухачами 3 планування, реалізації, оцінювання і корекції процесу навчання);

опора на досвід слухача (використання побутового, соціального та професійного досвіду слухача як джерела навчання);

індивідуалізація навчання (спільна розробка слухачем i викладачем індивідуальної програми навчання, яка зорієнтована на конкретні освітні потреби і цілі навчання, а також враховує досвід, рівень підготовки, психофізіологічні, когнітивні особливості слухача);

системність навчання (відповідність цілей, змісту, форм, методів, засобів навчання і оцінювання його результатів);

контактність навчання (з одного боку, спрямовується на конкретні, життєво важливі для слухача цілі, орієнтовані на виконання соціальних ролей або вдосконалення особистості, а 3 іншого - будується 3 врахуванням професійної, соціальної і побутової діяльності слухача і його просторових, часових i побутових факторів, умов);

актуалізація результатів навчання (невідкладне застосування на практиці отриманих слухачами знань, умінь, навичок, якостей);

ефективність навчання (надання слухачам певної свободи вибору цілей, змісту, методів, джерел, термінів, часу, місця i оцінювання результатів навчання, а також самих викладачів);

розвиток освітніх потреб (оцінювання результатів навчання здійснюється шляхом виявлення реального рівня засвоєння навчального матеріалу; при цьому процес навчання будується 3 метою формування у слухачів нових освітніх потреб, конкретизація яких здійснюється після досягнення певної мети навчання);

інноваційність (застосування інтерактивних форм, методів і засобів навчання); 
Науковий вісник: Державне управління № 4(6)2020

усвідомленість навчання (усвідомлення й осмислення слухачами всіх параметрів процесу навчання і своїх дій з його організації);

інтеграція - ключовий принцип сучасних політичних, економічних, соціокультурних процесів у провідних Європейських країнах, що визначає характер реалізації всіх елементів навчального процесу: цілей, змісту, організації тощо.

Актуальність змісту підвищення кваліфікації має віддзеркалювати новітні тенденції розвитку системи освіти, іiї інноваційну спрямованість, перехід на нову структуру та зміст, створювати передумови для опанування педагогами нових педагогічних технологій [12].

Враховуючи можливість запровадження різних моделей підвищення кваліфікації управлінських кадрів, участь в організації цього процесу різних суб’єктів надання освітніх послуг - навчальних закладів, методичних установ та громадських організацій, фізичних осіб-провайдерів освітніх послуг, потребує запровадження стандартних (або типових) професійних програм підвищення їх кваліфікації.

Структурованість змісту навчальних планів підвищення кваліфікації управлінських кадрів передбачає наявність чіткого його розподілу на окремі галузі знань, розділи, теми, що є важливим для визначення змістових модулів.

Варіативність змісту навчальних планів підвищення кваліфікації полягає у тому, що крім обов'язкової складової змісту підвищення кваліфікації, зазначеної в інваріантній частині навчальних планів, має бути передбачений той обсяг змісту, який можуть замовляти органи державної влади, окремі навчальні заклади, а також вибирати викладачі та слухачі 3 урахуванням регіональних або особистісних потреб суб'єктів професійного розвитку.

Диференціація змісту навчальних планів підвищення кваліфікації характеризується врахуванням освітніх потреб та наявного рівня професіоналізму різних категорій 
Науковий вісник: Державне управління № 4(6)2020

управлінських кадрів, зокрема, стаж, досвід, атестаційну категорію, напрями діяльності тощо.

За результатами аналізу принципів $[13,14]$, покладених в основу змісту підвищення кваліфікації управлінських кадрів, ми їх класифікували на ті, що сприяють:

інноваційному розвитку системи підвищення кваліфікації керівних кадрів на сучасному етапі (табл. 2);

розвитку кредитно-модульної форми організації навчання на курсах підвищення кваліфікації управлінських кадрів (табл. 3).

Табличя 2 - Принципи, що сприяють інноваційному розвитку системи підвищення кваліфікації керівних кадрів

\begin{tabular}{|c|c|c|}
\hline \multirow[t]{2}{*}{ Принцип } & \multicolumn{2}{|c|}{ Відображення } \\
\hline & зміст навчання & структура навчання \\
\hline глобалізм & $\begin{array}{l}\text { Ознайомлення i3 } \\
\text { сучасними проблемами } \\
\text { iнтеграції }\end{array}$ & $\begin{array}{l}\text { Запровадження } \\
\text { додаткових } \\
\text { навчальних заходів }\end{array}$ \\
\hline гуманізм & $\begin{array}{l}\text { Розвиток } \\
\text { гуманістичних якостей } \\
\text { особистості }\end{array}$ & $\begin{array}{l}\text { Спеціальні } \text { навчальні } \\
\text { модулі }\end{array}$ \\
\hline інноваційність & $\begin{array}{l}\text { Ознайомлення } \\
\text { освітніми інноваціями }\end{array}$ & $\begin{array}{l}\text { Застосування } \\
\text { інноваційних форм і } \\
\text { методів організації та } \\
\text { самого навчання }\end{array}$ \\
\hline інформаційність & $\begin{array}{l}\text { Оволодіння сучасними } \\
\text { інформаційно- } \\
\text { комунікаційними } \\
\text { технологіями }\end{array}$ & $\begin{array}{l}\text { Застосування } \\
\text { інформаційно- } \\
\text { комунікаційних } \\
\text { технологій } \\
\text { iндивідуальної } \\
\text { навчання }\end{array}$ \\
\hline науковість & $\begin{array}{l}\text { Ознайомлення із } \\
\text { сучасними здобутками } \\
\text { науки і техніки }\end{array}$ & $\begin{array}{l}\text { Співвідношення } \\
\text { теоретичних } \\
\text { практичних знань }\end{array}$ \\
\hline
\end{tabular}


Таблиця 3 - Основні принципи організації підвищення кваліфікації керівних кадрів

\begin{tabular}{|c|c|c|}
\hline Принцип & $\begin{array}{c}\text { Відображення у змісті } \\
\text { навчання }\end{array}$ & $\begin{array}{c}\text { Відображення у } \\
\text { структурі навчання }\end{array}$ \\
\hline Самостійності & $\begin{array}{l}\text { Активний та } \\
\text { інтерактивний методи }\end{array}$ & $\begin{array}{l}\text { Заочно-дистанційне } \\
\text { навчання }\end{array}$ \\
\hline $\begin{array}{l}\text { Індивідуалізації та } \\
\text { диференціації }\end{array}$ & $\begin{array}{l}\text { Індивідуальний } \\
\text { навчальний } \\
\text { графік }\end{array}$ & $\begin{array}{l}\text { Кредитно-модульна } \\
\text { система навчання }\end{array}$ \\
\hline Елективності & $\begin{array}{l}\text { Вільний вибір тем } \\
\text { випускних } \\
\text { кваліфікаційних робіт }\end{array}$ & Тестовий контроль \\
\hline Мотивації у навчанні & $\begin{array}{l}\text { Виступи на } \\
\text { семінарських заняттях і } \\
\text { визначення ролі при } \\
\text { участі в кейсах }\end{array}$ & Комплексний \\
\hline $\begin{array}{l}\text { Варіативності змісту і } \\
\text { форм навчання }\end{array}$ & $\begin{array}{l}\text { Самостійний свідомий } \\
\text { вибір тем навчання при } \\
\text { кредитно-модульній } \\
\text { системі }\end{array}$ & $\begin{array}{lr}\text { Врахування } & \text { інтересів } \\
\text { слухача } & \text { при } \\
\text { плануванні } & \text { i } \\
\text { проведенні тренінгів } \\
\text { факультативів } \\
\end{array}$ \\
\hline $\begin{array}{l}\text { Поваги до суб’єктів } \\
\text { навчання }\end{array}$ & $\begin{array}{l}\text { Діагностування } \\
\text { особистих } \\
\text { та якостей }\end{array}$ & $\begin{array}{l}\text { Діагностування } \\
\text { особистих } \\
\text { та якостей }\end{array}$ \\
\hline $\begin{array}{l}\text { Проблемності у } \\
\text { навчанні }\end{array}$ & $\begin{array}{l}\text { Створення проблемних } \\
\text { ситуацій на занятті } 3 \\
\text { використанням кейс- } \\
\text { методу }\end{array}$ & 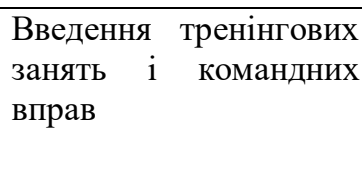 \\
\hline
\end{tabular}

(розроблено на підставі [0])

За даними табл. 2 у змісті підвищення кваліфікації керівних кадрів принцип глобалізму забезпечується ознайомленням слухачів 3 проблемами функціонування глобалізованого світу; принцип гуманізму - розвитком гуманістичних якостей особистості; принцип інноваційності ознайомленням 3 управлінськими інноваціями; принцип інформаційності - оволодінням інформаційнокомунікаційними технологіями; принцип науковості ознайомленням із сучасними досягненнями науки і освіти. 
У структурі підвищення кваліфікації: принцип глобалізму сприяє запровадженню додаткових семінарів і спецкурсів; принцип гуманізму - вибору змісту навчання у варіативній складовій; принцип інноваційності - застосуванню інноваційних форм організації навчання (кредитно-модульна, очно-дистанційна, пролонгована тощо); принцип інформаційності - застосуванню інформаційнокомунікаційних технологій для індивідуальної форми навчання; принцип науковості - співвідношенню теоретичних і практичних занять.

Важливими принципами організації навчального процесу при підвищенні кваліфікації управлінських кадрів є:

провідної ролі самостійності у навчанні, що проявляються у змісті навчання через активні й інтерактивні форми і методи; у структурі навчання - через очно-дистанційну форму організації навчання;

проблемно-пошукової організації змісту навчання - через створення проблемних ситуацій на заняттях і введення нових форм підвищення кваліфікації таких як ситуаційні вправи, ділові ігри, тренінги тощо;

індивідуалізації і диференціації - через розробку індивідуальних планів підвищення кваліфікації і кредитномодульної форми навчання слухачів;

елективності - через вільний вибір теми випускної творчої роботи і спецкурсів та виконання завдань тестового контролю (вхідного, поточного, вихідного);

мотивації і розвитку творчого потенціалу - через активну участь слухачів курсів підвищення кваліфікації на семінарських і практичних заняттях та у спільному складанні комплексного заліку чи іспиту;

варіативності - через задоволення індивідуальних запитів, пізнавальних та інтелектуальних інтересів i можливостей слухачів у підвищенні кваліфікаціі; 


\section{Науковий вісник: Державне управління № 4(6)2020}

науковості - через наповнення новим змістом навчальних занять на засадах андрагогіки, синергетики, інноватики, менеджменту, парламентаризму тощо.

Зазначена вище система принципів відбору змісту навчання й організації навчального процесу сприяють забезпеченню цілісності, наступності і безперервності професійного розвитку управлінських кадрів.

Що стосується специфіки підвищення кваліфікації управлінських кадрів сфери цивільного захисту. Визначення змісту підвищення кваліфікації керівних кадрів відбувається під впливом політичних і соціально-економічних змін, які відбуваються в суспільстві, у тому числі і в сфері цивільного захисту. Крім того, виявляє тенденцію орієнтації не лише на вимоги держави, а й на особистісні і професійні запити слухачів; спрямовується на оновлення всієї системи безперервного професійного розвитку управлінських кадрів, а саме: на врахування тенденцій розвитку суспільства, на опанування нового змісту та освітніх технологій, на впровадження інновацій, на розвиток уміння зіставляти локальні проблеми своєї професійної діяльності із загальнодержавними пріоритетами, на вмотивованість власного професійного зростання.

Нагальною потребою $є$ підготовка висококваліфікованих фахівців у галузі управління та адміністрування, здатних розв'язувати комплексні проблеми з публічного управління та адміністрування для запобігання i реагування на $\mathrm{HC}$, прийняття управлінських рішень в умовах НС і налагодження кризових комунікацій в процесі ліквідації наслідків НС. Навчання має відбуватися за алгоритмом, притаманним будьяким управлінським спеціальностям: фундаментальні знання стратегії- застосування в екстремальних умовах.

У зв'язку з тим, що навчання в системі підвищення кваліфікації грунтується на сукупності перелічених принципів навчання, постає завдання створення абсолютно нових професійних і спеціальних програм підвищення кваліфікації 
Науковий вісник: Державне управління № 4(6)2020

управлінських кадрів. Вони мають бути модульними, гнучкими, технологічними. Їх основу мають становити сучасні вимоги до посади керівника, його професійних категорій та компетентності.

Необхідний набір навичок для професіоналів-управлінців сфери цивільного захисту допомогли сформулювати дослідження системи спеціальної методології для навчань експертів з реагування у разі виникнення масштабних НС у межах спільного проекту Україна - Королівство Швеція «Стандартизація українського кризового управління у сфері реагування на надзвичайні ситуації» та тренінгів 3 питань кризового управління у разі НС радіаційного, хімічного, біологічного та ядерного характеру під егідою Федерального відомства цивільного захисту та допомоги при катастрофах Федеративної Республіки Німеччина (ВВК).

Базовою програмою підготовки управлінців у сфері цивільного захисту можна вважати освітньо-професійну програму підготовки магістрів за спеціальністю 281 «Публічне управління та адміністрування», спеціалізація «Управління у сфері цивільного захисту». Цю програму започатковано з 2018 року в Інституті державного управління у сфері цивільного захисту [20].

Крім того, в ДСНС функціонує стала система підвищення кваліфікації управлінських кадрів, яка складається iз професійних програм підвищення кваліфікації та короткострокових семінарів, тренінгів, спрямованих на формування певних компетентностей у професійній сфері.

Професійною програмою підвищення кваліфікації, за якою проводиться підвищення кваліфікації апарату ДСНС $\epsilon$ підвищення кваліфікації державних службовців категорій посад Б та В у сфері цивільного захисту.

До основних складових змісту підвищення кваліфікації управлінських кадрів відносяться такі змістові елементи програми: 
Науковий вісник: Державне управління № 4(6)2020

основи організації сучасного державного управління та державної служби;

механізми прийняття управлінських рішень органами державної влади;

психологічні особливості управлінської діяльності;

елементи й етапи комунікативного процесу;

особливості поточного та перспективного планування як власної діяльності, так і діяльності підрозділу;

порядок здійснення підготовки населення на підприємствах, в установах та організаціях до дій при виникненні надзвичайних ситуацій техногенного та природного характеру;

організацію взаємодії між центрами управління в надзвичайних ситуаціях, оперативно-черговими службами уповноважених органів 3 питань надзвичайних ситуацій та цивільного захисту населення усіх рівнів, диспетчерськими службами центральних і місцевих органів виконавчої влади, державних підприємств, установ, та організацій, регламент подання інформації при надзвичайних ситуаціях;

функції керівника при ліквідації надзвичайної ситуації.

Крім того, перед початком навчання проводиться опитування майбутніх слухачів щодо їх запитів на отримання новітніх знань та умінь, та складається варіативна змістова частина програми саме для конкретної навчальної групи.

Сучасний зміст - важлива складова сучасної системи підвищення кваліфікації. Однак її ефективність залежить від вдало «...підібраної системи створення, застосування i визначення процесу викладання i засвоєння знань 3 урахуванням технічних i людських ресурсів та їх взаємодії...» (ЮНЕСКО) - педагогічної технології.

До інноваційних технологій навчання у сучасній системі підвищення кваліфікації управлінських кадрів ми відносимо:

технологію програмованого навчання - програмнометодичний комплекс, який дає можливість самостійно 
засвоїти навчальний курс або його певний розділ і об'єднує в собі властивості звичайного підручника, довідника, збірника задач і лабораторного практикуму;

медіа-технологію - вид дистанційної технології навчання, що базується на використанні систем телебачення для доставки слухачам навчально-методичних матеріалів та організації регулярних консультацій у викладачів (тьюторів);

мережеву технологію - вид дистанційної технології навчання, що базується на використанні мереж телекомунікації для забезпечення слухачів навчальнометодичними матеріалами та інтерактивної взаємодії між викладачем (тьютором);

кейс-технологію - вид дистанційної технології навчання, яка заснована на використанні наборів (кейсів) текстових, аудіовізуальних та мультимедійних навчально-методичних матеріалів для їх самостійного вивчення слухачами при організації регулярних консультацій у викладачів (тьюторів) традиційним або дистанційним способом.

Найбільшу практику в Інституті набула кейс-технологія. Цінність кейс-технології полягає в тому, що вона одночасно відображає не тільки практичну проблему, а й актуалізує певний комплекс знань, який необхідно засвоїти при вирішенні проблеми, а також вдало суміщає навчальну, аналітичну i виховну діяльність, що безумовно $є$ діяльним $\mathrm{i}$ ефективним в реалізації сучасних завдань системи освіти.

Як зазначають вітчизняні дослідники [12, 16], застосування викладачем кейс-методу з одного боку стимулює індивідуальну активність слухачів, формує позитивну мотивацію до навчання, зменшує масив "пасивних" i невпевнених у собі слухачів, забезпечує високу ефективність навчання i розвитку майбутніх фахівців, формує певні особистісні якості і компетенції, а з іншого - дає можливість викладачу самовдосконалюватись. 
Науковий вісник: Державне управління № 4(6)2020

Висновки та напрями подальших досліджень. Реформування системи цивільного захисту держави, яке було проведене останніми роками, життя в умовах ринкових відносин, новітніх інформаційних технологій, закордонний досвід розвинутих держав потребує переосмислення існуючої практики підготовки кадрів для реалізації заходів безпеки населення і територій України з урахуванням європейських стандартів управління ризиками.

До основних складових змісту програм підвищення кваліфікації управлінських кадрів в суб'єктах надання освітніх послуг мають відносити змістові модулі: законодавчої, культуротворчої та українознавчої спрямованості; світоглядної (сучасної методологічної), психологічної й фасилітативної підготовки; 3 філософії, політики, парламентаризму, державного управління, права, інноватики, інформатики тощо.

3 метою спеціальної підготовки державних управлінців сфери цивільного захисту потребують удосконалення існуючі програми підвищення кваліфікації державних службовців у сфері цивільного захисту за рахунок запровадження змішаного (дистанційного) навчання.

Визначення змісту підвищення кваліфікації керівних кадрів відбувається під впливом політичних i соціальноекономічних змін, які відбуваються в суспільстві; виявляє тенденцію орієнтації не лише на вимоги держави, а й на особистісні і професійні запити слухачів; спрямовується на оновлення всієї системи безперервного професійного розвитку управлінських кадрів, а саме: на врахування тенденцій розвитку суспільства, на опанування нового змісту та освітніх технологій, на впровадження інновацій, на розвиток уміння зіставляти локальні проблеми своєї професійної діяльності із загальнодержавними пріоритетами, на вмотивованість власного професійного зростання.

Механізмом реалізації безпекової теорії $\epsilon$ публічне управління у сфері цивільного захисту, що має мультидисциплінарний характер, поєднуючи методологію та 
Науковий вісник: Державне управління № 4(6)2020

інструментарій супільно-гуманітарних, природничих і технічних наук, опрацьовуючи новий безпековий світогляд, культуру сталого розвитку.

Ефективність професійної діяльності фахівців у сфері цивільного захисту, пов'язана 3 понаднормованими психоемоційними i фізичними навантаженнями, має бути забезпечена застосуванням високотехнологічних та інноваційних методів навчання 3 урахуванням специфіки діяльності органів управління і підрозділів служби цивільного захисту під час виникнення надзвичайних ситуацій та ліквідації їх наслідків.

Зважаючи на це, функціональна компетентність, тобто знання і вміння виконувати певні типи діяльності та типові для даної функції завдання діяльності, для публічних управлінців у сфері цивільного захисту стає головним видом компетенції, що грунтується на аналізі причин виникнення надзвичайних ситуацій і дій відповідних органів управління та оперативнорятувальних підрозділів.

Ефективною педагогічною технологію, що застосовується в системі підвищення кваліфікації управлінських кадрів в сфері цивільного захисту, що доведено практикою іiі застосування, є кейс-технологія.

Враховуючи епідеміологічну ситуацію 3 COVID-19, перспективним вважається застосування медіа-технологій як перспективного виду дистанційної технології підвищення кваліфікації. Ця технологія базується на використанні сучасних телекомунікаційних систем i дозволить зробити процес навчання гнучким та адаптивним під потреби конкретного управлінця. Сдиною перешкодою для широкого застосування даної технології може бути недостатня якість інтернету.

Враховуючи зазначене, перспективним напрямом подальших досліджень може бути теоретико-методологічне обгрунтування та розробка алгоритму проведення підвищення кваліфікації управлінців сфери цивільного захисту 3 
Науковий вісник: Державне управління № 4(6)2020

використанням сучасних телекомунікаційних технологій у дистанційному форматі.

\section{Список використаних джерел}

1. Бакуменко В. Д. Формування державно-управлінських рішень: проблеми теорії, методології, практики : монографія. К. : Вид-во УАДУ, 2000. 328 с.

2. Антонюк О. С. Організація системи професійного навчання публічних службовців у Польщі: досвід для України: мат. щорічн. наук.-практ. конф. 3 міжнар. участю «Свропейські принципи і стандарти підготовки публічних управлінців: орієнтири для України» (5-6 лист. 2015р., Київ). К., 2015. C. 95 .

3. Грабар Н. С. Перепідготовка та підвищення кваліфікації державних службовців в Японії: досвід для України/ «Європейські принципи і стандарти підготовки публічних управлінців: орієнтири для України». Мат. щорічн. наук.практ. конф. 3 міжнар. участю (5-6 лист. 2015p., Київ). К., 2015. С. 122.

4. Дракохруст Т. В. Питання щодо можливості адаптації зарубіжних технологій підвищення кваліфікації державних службовців. «Свропейські принципи і стандарти підготовки публічних управлінців: орієнтири для України». Мат. щорічн. наук.-практ. конф. 3 міжнар. участю (5-6 лист. 2015р., Київ). К., 2015. С. 139-141.

5. Прокопенко Л., Щербаков П. Свропейські підходи до підвищення кваліфікації публічних службовців. Державне управління та місчеве самоврядування. 2012. Вип. 3 (14). C. $154-162$.

6. Черчатий О. І., Трегубенко Г. П. Вивчення та впровадження в Україні іноземного досвіду підвищення професійної компетентності працівників органів влади. Aспекти публічного управління. 2014. № 5-6 (7-8). С. 63-70.

7. Долгий М. Л., Євсюков О. П., Терент'єва А. В. Оптимізація підвищення кваліфікації державних службовців у сфері цивільного захисту. Економіка та держава. 2013. № 6. C. $116-118$.

8. Долгий М. Л., Євсюков О. П., Терент'єва А. В. Сучасні тенденції підготовки державних службовців у сфері 
цивільного захисту. Інвестиції: практика $i$ досвід. 2013. № 6. С. 125-128.

9. Витко Т. Ю. Свропейський досвід функціонування системи навчання публічних службовців. «Європейські принципи i стандарти підготовки публічних управлінців: орієнтири для України». Мат. щорічн. наук.-практ. конф. 3 міжнар. участю (5-6 лист. 2015р., Київ). К., 2015. С. 98.

10. Гошовська В. А. Навчання державних службовців та осіб місцевого самоврядування в контексті європейського виміру системи підвищення кваліфікації. «Свропейські принципи і стандарти підготовки публічних управлінців: орієнтири для України». Мат. щорічн. наук.-практ. конф. 3 міжнар. участю (5-6 лист. 2015р., Київ). К., 2015. С. 90.

11. Федорчук В. А. Організаційно-правове забезпечення кадрової політики в державному управлінні. Вісник НАДУ при Президентові України. - 2015. - № 1. - С. 23-29.

12. Теоретичні та організаційно-методичні

засади проектування освітньої діяльності навчально-методичних установ цивільного захисту : монографія (з електрон. дод.). вид. 2, переробл. / Литвиновський С. Ю. та ін. Львів: Кругозір, 2017. 230 с.

13. Свропейські принципи і стандарти підготовки публічних управлінців: орієнтири для України : матеріали щоріч. наук.-практ. конф. за міжнар. участю (Київ, 5-6 листоп. 2015 р.) /за заг. ред. Ковбасюка Ю. В. та ін. К. : НАДУ, 2015. $312 \mathrm{c}$.

14. Марценюк О. О. Професіографічний підхід до формування соціально-психологічної компетентності керівника в системі державного управління. Державне будівництво. $2008 . \quad$ Вип. $2 . \quad$ URL : http://nbuv.gov.ua/UJRN/DeBu_2008_2_50 (дата звернення: 18.10.2019).

15. Ларіна Н. Б. Інноваційні моделі підвищення кваліфікації управлінських кадрів : навч.-метод. матеріали. К. : НАДУ, 2013. 52 c.

16. Волянський П. Б. Ковровський Ю. Г., Михайлов В. М. Застосування інтерактивних освітніх технологій у навчанні керівного складу і фахівців, діяльність яких пов'язана 3 організацією та здійсненням заходів 3 питань цивільного захисту. Молодь і ринок. 2019. № 5(172). С. 29-38. 
Науковий вісник: Державне управління № 4(6)2020

17. Недашківська Т. С. Професійність державних службовців: компетентнісний підхід. Вісник НАДУ при Президентові України. 2008. № 1. С. 73-82.

18. Proposal for a Recommendation of the European Parchment and of the Council on the establish-ment of the European Qualifications Framework for lifelong learning. Commission of the European Communities. Brussells, 05.09.2006. COM (2006) 479 final. 2006/0163 (COD).

19. Волянський П. Б., Євсюков О. П., Терент'єва А. В. Імітаційне моделювання у процесі підготовки управлінців у сфері цивільного захисту. Науковий вісник НУЦЗУ. Сер.: Державне управління. 2017. №1(6). С. 229-236.

20. Освітньо-професійна програма «Управління у сфері цивільного захисту» // Вебсайт ІДУ НД ЦЗ / ІДУ НД ЦЗ. URL : https://bit.ly/3kkRqt3 (дата звернення: 20.09.2020).

\section{References}

1. Bakumenko, V. D. (2000). Formuvannia derzhavnoupravlinskykh rishen: problemy teorii, metodolohii. Praktyky [Formation of public administration decisions: problems of theory, methodology. Practices]. Kyiv: NUADP [in Ukrainian].

2. Antoniuk, O. S. (2015). Orhanizatsiia systemy profesiinoho navchannia publichnykh sluzhbovtsiv u Polshchi: dosvid dlia Ukrainy [Organization of the system of professional training of public servants in Poland: experience for Ukraine]. Proceedings from MIIM: Shchorichna naukovo-praktychna konferentsiia $z$ mizhnarodnoiu uchastiu «Ievropeiski pryntsypy $i$ standarty pidhotovky publichnykh upravlintsiv: oriientyry dlia Ukrainy»Annual scientific-practical conference with international participation «European principles and standards of training of public managers: guidelines for Ukraine». (p. 95). Kyiv [in Ukrainian].

3. Hrabar, N. S. (2015). Perepidhotovka ta pidvyshchennia kvalifikatsii derzhavnykh sluzhbovtsiv v Yaponii: dosvid dlia Ukrainy [Retraining and advanced training of civil servants in Japan: experience for Ukraine]. Proceedings from MIIM: Shchorichna naukovo-praktychna konferentsiia z mizhnarodnoiu uchastiu «Ievropeiski pryntsypy $i$ standarty pidhotovky publichnykh upravlintsiv: oriientyry dlia Ukrainy» - Annual scientific-practical conference with international participation «European principles and standards of training of public 
managers: guidelines for Ukraine». (p. 122). Kyiv [in Ukrainian].

4. Drakokhrust, T. V. (2015). Pytannia shchodo mozhlyvosti adaptatsii zarubizhnykh tekhnolohii pidvyshchennia kvalifikatsii derzhavnykh sluzhbovtsiv [Questions about the possibility of adapting foreign technologies for advanced training of civil servants]. Proceedings from MIIM: Shchorichna naukovopraktychna konferentsiia z. mizhnarodnoiu uchastiu «Ievropeiski pryntsypy $i$ standarty pidhotovky publichnykh upravlintsiv: oriientyry dlia Ukrainy» - Annual scientific-practical conference with international participation "European principles and standards of training of public managers: guidelines for Ukraine». (pp. 139 - 134). Kyiv [in Ukrainian].

5. Prokopenko, L., \& Shcherbakov, P. (2012). Yevropeiski pidkhody do pidvyshchennia kvalifikatsii publichnykh sluzhbovtsiv [European approaches to professional development of civil servants]. Derzhavne upravlinnia ta mistseve samovriaduvannia - Public administration and local selfgovernment, 3(14), 154-162 [in Ukrainian].

6. Cherchatyi, O. I., \& Trehubenko H. P. Vyvchennia ta vprovadzhennia v Ukraini inozemnoho dosvidu pidvyshchennia profesiinoi kompetentnosti pratsivnykiv orhaniv vlady Aspekty publichnoho upravlinnia [Study and implementation in Ukraine of foreign experience in improving the professional competence of government officials Aspects of public administration]. Aspekty publichnoho upravlinnia - Aspects of public administration, 2014, № 5-6 (7-8), 63-70 [in Ukrainian].

7. Dolhyi M. L., Yevsiukov O. P., \& Terentieva A. V. Optymizatsiia pidvyshchennia kvalifikatsii derzhavnykh sluzhbovtsiv u sferi tsyvilnoho zakhystu [Optimization of advanced training of civil servants in the sphere of the civil protection]. Ekonomika ta derzhava - Economy and state, 2013, № 6, 116 - 118 [in Ukrainian].

8. Dolhyi M. L., Yevsiukov O. P., \& Terentieva A. V. Suchasni tendentsii pidhotovky derzhavnykh sluzhbovtsiv $u$ sferi tsyvilnoho zakhystu [Current trends in the training of civil servants in the sphere of the civil protection]. Investytsii: praktyka $i$ dosvid - Investments: practice and experience, 2013, № 6, 125 - 128 [in Ukrainian].

9. Vytko, T. Iu. (2015). Yevropeiskyi dosvid funktsionuvannia systemy navchannia publichnykh sluzhbovtsiv [European experience of functioning of the system of training of public 
Науковий вісник: Державне управління № 4(6)2020

servants]. Proceedings from MIIM: Shchorichna naukovopraktychna konferentsiia $z$ mizhnarodnoiu uchastiu «Ievropeiski pryntsypy $i$ standarty pidhotovky publichnykh upravlintsiv: oriientyry dlia Ukrainy» - Annual scientific-practical conference with international participation "European principles and standards of training of public managers: guidelines for Ukraine». (p. 98). Kyiv [in Ukrainian].

10. Hoshovska, V. A. (2015). Navchannia derzhavnykh sluzhbovtsiv ta osib mistsevoho samovriaduvannia v konteksti yevropeiskoho vymiru systemy pidvyshchennia kvalifikatsii [Training of civil servants and local governments in the context of the European dimension of the training system]. Proceedings from MIIM: Shchorichna naukovo-praktychna konferentsiia $z$ mizhnarodnoiu uchastiu «Ievropeiski pryntsypy $i$ standarty pidhotovky publichnykh upravlintsiv: oriientyry dlia Ukrainy»Annual scientific-practical conference with international participation «European principles and standards of training of public managers: guidelines for Ukraine». (p. 90). Kyiv [in Ukrainian].

11. Fedorchuk, V. A. Orhanizatsiino-pravove zabezpechennia kadrovoi polityky $\mathrm{v}$ derzhavnomu upravlinni [Organizational and legal support of personnel policy in public administration]. Visnyk NADU pry Prezydentovi Ukrayiny - NAPA Bulletin under the President of Ukraine, 2015, № 1, 23-29 [in Ukrainian].

12. Lytvynovskyi Ye. Yu., Behun V. V., Heldash S. V. Et al. (2017). Teoretychni ta orhanizatsiino-metodychni zasady proektuvannia osvitnoi diialnosti navchalno-metodychnykh ustanov tsyvilnoho zakhystu [Theoretical and organizationalmethodical bases of designing educational activity of educational-methodical establishments of civil protection]. Lviv: Kruhozir [in Ukrainian].

13. Proceedings from MIIM: Shchorichna naukovo-praktychna konferentsiia z mizhnarodnoiu uchastiu «Ievropeiski pryntsypy i standarty pidhotovky publichnykh upravlintsiv: oriientyry dlia Ukrainy» - Annual scientific-practical conference with international participation «European principles and standards of training of public managers: guidelines for Ukraine». . Kyiv, 2015 [in Ukrainian].

14. Martseniuk, O. O. (2008). Profesiohrafichnyi pidkhid do formuvannia sotsialno-psykholohichnoi kompetentnosti kerivnyka V systemi derzhavnoho upravlinnia [Professional 
approach to the formation of socio-psychological competence of the head in the system of public administration]. Derzhavne budivnytstvo - State building, 2. Retrieved from http://nbuv.gov.ua/UJRN/DeBu_2008_2_50 [in Ukrainian].

15. Larina, N. B. (2013). Innovatsiyni modeli pidvyshchennya kvalifikatsiyi upravlins'kykh kadriv [Innovative models of management training]. Kyiv: NAPA [in Ukrainian].

16. Volianskyi, P. B. Kovrovskyi, Yu. H., Mykhailov V. M. (2019). Zastosuvannia interaktyvnykh osvitnikh tekhnolohii $u$ navchanni kerivnoho skladu i fakhivtsiv, diialnist yakykh poviazana $\mathrm{z}$ orhanizatsiieiu ta zdiisnenniam zakhodiv $\mathrm{z}$ pytan tsyvilnoho zakhystu [The use of interactive educational technologies in the training of management and professionals whose activities are related to the organization and implementation of measures for civil protection]. Molod $i$ rynok - Youth and the market, № 5(172), 29-38 [in Ukrainian].

17. Nedashkivska, T. Ye. (2008) Profesiynist derzhavnykh sluzhbovtsiv: kompetentnisnyy pidkhid [Professionalism of civil servants: a competency approach]. Visnyk NADU - NAPA Bulletin, 1,73-82 [in Ukrainian].

18. Proposal for a Recommendation of the European Parchment and of the Council on the establish-ment of the European Qualifications Framework for lifelong learning. Commission of the European Communities. Brussells, 05.09.2006. COM (2006) 479 final. 2006/0163 (COD).

19. Volianskyi P.B., Yevsiukov O.P., \& Terentieva A.V. (2017). Imitatsiyne modelyuvannya $\mathrm{u}$ protsesi pidhotovky upravlintsiv $\mathrm{u}$ sferi tsyvilnoho zakhystu [Simulation in the process of training managers in the sphere of the civil protection]. Naukovyy visnyk NUTSZU. Ser.: Derzhavne upravlinnya - Scientific Bulletin of NUTSZU. Ser .: Public Administration, 1(6), 229-236 [in Ukrainian].

20. Osvitno-profesiina prohrama «Upravlinnia u sferi tsyvilnoho zakhystu» // Vebsait IDU ND TsZ / IDU ND TsZ. URL : https://bit.ly/3kkRqt3 (data zvernennia: 20.09.2020) [in Ukrainian]. 


\section{ORGANIZATIONAL AND METHODOLOGICAL PRINCIPLES OF CONTENT SELECTION OF THE LATEST TECHNOLOGIES OF IMPROVEMENT OF QUALIFICATION OF MANAGEMENT STAFF OF THE CIVIL SPHERE}

Yevsyukov Oleksandr, Dr Sc. (Pbl Adm.), Assoc. Prof., Professor of the Department of Public Administration in the Sphere of Civil Protection, Institute of Public Administration and Research in Civil Defense, Kyiv, Vyshgorodskaya, 21, tel. 044-496-81-64, e-mail : kafedra dsunmp@ukr.net , https://orcid.org/0000-0001-8586-9896

Gavaza Andriy, Lecturer of the Department of Public Administration in the Field of Civil Defense, Institute of Public Administration and Research in Civil Defense, Kyiv, Vyshgorodskaya, 21, tel. 044-496-81-64, https://orcid.org/0000-0002-7205-410X

Abstract. The reform of the civil protection system of the state, which was carried out in recent years, living in market conditions, the latest information technologies, foreign experience of developed countries requires a rethinking of existing training practices to implement security measures of the population and territories of Ukraine. The main components of the content of advanced training of managerial staff in the institutes of advanced training and free economic zones should include content modules: legislative, cultural and Ukrainian studies; worldview (modern methodological), psychological and facilitative training; in philosophy, politics, parliamentarism, public administration, law, innovation, computer science, etc. Determining the content of professional development of managers is under the influence of political and socio-economic changes taking place in society; shows a tendency to focus not only on the requirements of the state, but also on the personal and professional needs of students; aims to update the entire system of continuous professional development of management, namely: to take into account trends in society, to master new content and educational technologies, to innovate, to develop the ability to compare local problems of their professional activities with national priorities, to motivate their own professional growth. The mechanism for implementing security theory is public administration in the field of civil protection, which has a multidisciplinary nature, combining the methodology and tools of the humanities, natural and technical sciences, developing a new security worldview, a culture of sustainable development. The effectiveness of professional activities of specialists in the field of civil protection, associated with excessive psychoemotional and physical stress, should be ensured by the use of high-tech and innovative teaching methods, taking into account the specifics of government agencies and civil protection units. Given this, functional competence, ie knowledge and ability to perform certain types of activities and typical for this function tasks of activity, for public managers in the field of civil protection becomes the main type of competence.

Key words: managerial staff, civil defense, qualification, competence, training. 